\title{
Do-It-Yourself Flood Risk Adaptation Strategies in the Neighborhoods of Kano City, Nigeria
}

\author{
Aliyu Barau and Aliyu Sani Wada
}

\section{Contents}

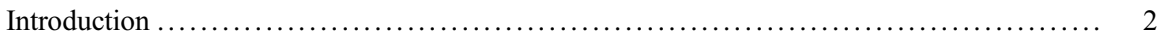

An Overview of Conceptualization of Flood Risk Adaptation ........................ 4

Observing the Nature of Flood Risk Situation in Kano City $\ldots \ldots \ldots \ldots \ldots \ldots \ldots \ldots \ldots \ldots \ldots \ldots$

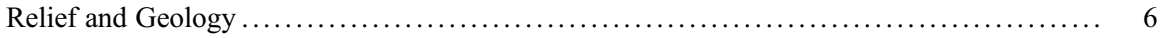

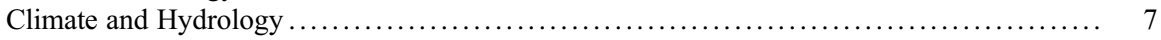

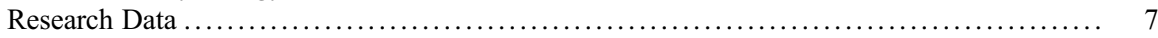

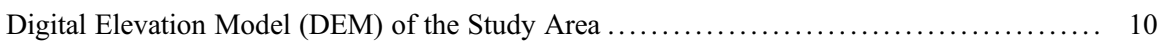

Socioeconomic Characteristics of the Residents .................................. 11

Socioeconomic Characteristics of the Respondent in the Study Area $\ldots \ldots \ldots \ldots \ldots \ldots \ldots \ldots . .11$

Public Perception and Current State of Flood Risk and Adaptation ..................... 14

Public and Institutional Adaptation Response to Floods in the Study Area ............... 17

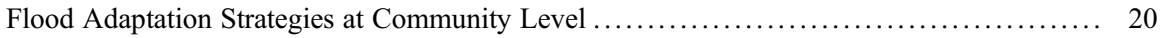

Post-flood Community Response on Adaptation Strategies ........................... 20

Institutional Flood Adaptation Response Strategies in the Study Area $\ldots \ldots \ldots \ldots \ldots \ldots \ldots \ldots .23$

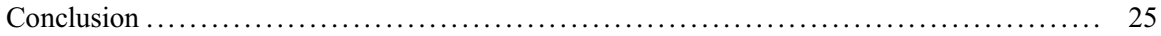

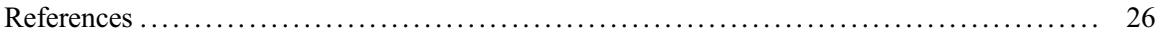

\section{Abstract}

The urban poor in developing countries is hit hardest by climate-related extreme events such as flooding. Also, informal settlements lacking municipal support and immediate public response to flooding incur losses and thus exacerbate their sufferings. Left out or left alone, the vulnerable people from some parts of the ancient city of Kano develop their own efforts to protect themselves against the recurrent flood events. Hence, this chapter examines the nature of communitydriven do-it-yourself (DIY) adaptation The data was collected through field-based surveys, interviews, and questionnaires to enable in-depth analysis of the problem from socioecological point of view. The results identified flood drivers to include

\footnotetext{
A. Barau $(\bowtie) \cdot$ A. S. Wada

Department of Urban and Regional Planning, Bayero University Kano, Kano, Nigeria

e-mail: asbarau.urp@buk.edu.ng; saniwada2@gmail.com
} 
the nature of surface topography, torrential rainfalls, lapses, and inadequacies in the availability of drainage infrastructure and human behavioral lapses in drainage management. On the other hand, the DIY adaptation manifests in the use of sandbags, de-siltation of drainage, construction of fences, and drainage diversions. It is important to highlight that DIY adaptation is a good strategy; however, municipal authorities must come to the aid of such communities and revisit the absence of urban planning by supporting them through capacity building to find more effective solutions to the challenges of the changing climate and environment.

\section{Keywords}

Planning $\cdot$ Households $\cdot$ Climate Change $\cdot$ Vulnerability $\cdot$ Informal

\section{Introduction}

Climate-related disasters continue to spread and affect the poorer populations in both urban and rural areas. It has been suggested that flooding is the most widespread climate extreme event that accounts for more than $40 \%$ of disasters globally (Nkwunonwo et al. 2016). It is also considered as the third most damaging disaster after storms and earthquakes (Wilby and Keenan 2012). It was estimated that the average annual number of people affected by floods is likely to increase from one million in the 1990s to 25 million by 2050 (Salami et al. 2016). Nevertheless, the increased awareness and concerns over climate change have reinforced the need for adjustments on how human use land and other resources in order to limit risks and vulnerabilities that originate from global climate change (Verburg et al. 2012). Besides climate change, many studies have attributed the exacerbation of flooding to the nature of population density and standard of living especially in the lived environments of developing countries (Devkota et al. 2014). In other words, this implies that built environments in developing countries are most exposed to flooding and hence more response actions are needed from within and outside the lived environment. Efforts from within involve action by individuals and municipalities, and action from outside may involve states and federal actions to strengthen resilience to flooding and climate change. Importantly, it is critical to also put in place modalities for communicating climate knowledge to public in order to enable proper response to climate crisis (Barau and Tanko 2018).

Researchers from developing and developed countries consider flood adaptation from different approaches. For instance, Alfieri et al. (2016) focused on adaptation measures for flood risk reduction by putting emphasis on adaptive measures such as relocation, reduction of vulnerability, reduction of peak flows, and increased flood protection levels. On the other hand, Barau (2008) focused on adaptation measures oriented toward institutional perception but fails to assess public adaptation strategies deployed to prevent flooding. Some authors suggested that relief materials including healthcare services supplied to flood victims in Nigeria were inefficient 
and paid too little attention given to efforts to reduce the future flood menace (Soneye 2014; Olanrewaju et al. 2019). Contrastingly, since the 1990s, the United States introduced the Community Rating System (CRS), a community-driven program that incentivizes local actions for addressing flood risk (Noonan and Sadiq 2018). It is apparent that climate change adaptation is not an exclusive business of the state or formal planning processes, but it goes down to efforts of communities and businesses to protect themselves (Colenbrander and Barau 2019; Udelsmann Rodrigues 2019). By implication, climate adaptation has become a concern of every stakeholder given the weakening resilience of urban areas in developing countries. Nevertheless, designing neighborhood or community resilience to flooding will benefit from understanding the social and ecological attributes of societies which are not limited to biophysical changes, infrastructure, mitigation planning, and public perceptions of extreme events (Parsons 2019). The potentials of grassroots action to address flooding in African countries are said to be a promising and effective self-defense mechanism in poorly serviced areas (Udelsmann Rodrigues 2019).

Flooding in Nigeria is the most common and recurring disaster with unprecedented damages caused by heavy rainfall and surface runoff which in 2012 in particular contributed to submergence of settlements along the Kainji, Jebba, and Shiroro dams in Niger State, the Lagdo dam in Cameroun located along the River Benue, the Kiri Dam on the River Gongola, and numerous additional irrigation dams (PDNA 2013). Consequently, this triggered the displacement of thousands of people and loss of lives and properties. According to the National Emergency Management Agency (NEMA), 363 people were killed, 5,851 injured, 3,891,314 affected, and $3,871,53$ displaced due to the resulting floods. Similarly, it is has been observed that flood disaster happens to be more frequent in Kano, Niger, Adamawa, Oyo, and Jigawa states possibly due to influence of river Benue, Niger and Ogun (Nkwunonwo et al. 2016).

Since the 1960s, the rainfall received in Kano region has exhibited notable fluctuations, however with increased flood incidents due to encroachment on environmentally sensitive areas such as floodplains along the ancient city walls which were traditionally reserved specifically for urban gardening (Barau et al. 2015). Studies revealed that between 2003 and 2007, Kano has experienced severe urban flood that claimed many lives and property - roughly 16, 730 households were affected, 14 people were reported dead - and many were displaced (Barau 2008). In addition, flood water contaminates and pollutes the environment with garbage; many factors are responsible for the recurrent flood events with prolong rainfall leading to large volume of water with tendency of overwhelming the infiltration capacity of the soil. This often yield to large surface runoff beyond the carrying capacity of the already narrowed drainages filled with garbage and simultaneously adjoined with poor maintenance which end up polluting the environment (Azua et al. 2019). It is apparent that damages to lives and property has become a cyclic phenomenon in Kano metropolis. It was also reported that 18, 397, 29, 151, and 177 people in 2003, 2004, 2005, 2006, and 2007, respectively, were affected in the Dala Local Government Area, due to impact of flood (Barau 2008). The aim of this chapter is to assess 
flood risk and adaptation measures in Dala Local Government Area in Kano city, Nigeria, and this is with a view to improving adaptation strategies in the area by identifying suitable and sustainable planning recommendations.

\section{An Overview of Conceptualization of Flood Risk Adaptation}

Floods can occur within a matter of minutes, and its effects can be local, impacting a neighborhood or a community; it can even go beyond a single community to affect the entire river basins and multiple areas (Wilby and Keenan 2012). Flood risk and flood-related losses may increase due to human activity or decrease through an appropriate flood management, planning, and adaptation strategies (Kubal et al. 2009). Human interventions in the natural processes such as increase in settlement areas, removal of biotic habitats, population growth, and economic assets over low-lying plains make them more prone to flooding especially when alterations of natural drainage and river basin patterns and deforestation are on the rise (Muo 2015). This situation is typical of what obtains from urban areas of developing countries including Nigeria which has the largest population in Africa. Hence, flooding and its impact on population is a socioecological challenge as it has links and feedbacks between human and natural systems. The socioecological system approach is said to be important in private flood hazard adaptation strategies (Fuchs et al. 2017).

Cirella and Iyalomhe (2019) categorized flooding on the basis of spatiality which includes coastal flooding and river flooding, while Dhiman et al. (2019) added urban and areal flooding to the list. In a situation whereby towns and cities are located on these types of landscapes and in the case where the most vulnerable populations are located on such marginal lands, the struggle with risks of sea-level rise becomes even more complicated. Another factor is the accumulation of rainwater in low-lying areas with a high water table, or inadequate storm drainage (Cirella and Iyalomhe 2019). In addition to this, the main causes of flooding as posited by same author are not limited to heavy rainfall, blockage of waterways, building on flood plains, and poor land use planning. According to Dhiman (2019), urbanization was the most important driver of flood risk in the cities where inadequate drainage system in combination with ineffective spatial planning increases the flood risk. Additional damages from the floods are also included in the framework where simulation using climate model and further downscaling indicate high potential sensitivity of flood risk to climate change.

Flooding with its numerous and varied impact causes mortalities, population displacement, and property damage which may also critically endanger sustainable development pathways (Vojtek and Vojteková 2016). The literature on flood health impact rarely quantifies or classifies the causes and circumstances of deaths which in many instances are also determined by the prevailing socioeconomic and health conditions of the affected communities (Jongman 2018). Flood impacts range from socioeconomic, psychological, cultural, to environmental impacts (Alfieri et al. 2016). The economic impacts include damage to public buildings, public utility 
works, housing and household assets, losses in industry, and business trade. Other losses are those affecting petty shopkeepers, low-income earners, loss of revenue, and interruption of road and railway transportation. Flooding also triggers the outbreak of infectious diseases, e.g., fever, pneumonic plagues, dysentery, and common cold among others.

On the other hand, Devkota et al. (2014) identified the following responses of adaptation strategies at community level undertaken before, during, and after flood event. Responses identified before flood event include management plans, keeping contact information, pre-estimating of flood risk, and producing human resources/ trained manpower. Response strategies undertaken during the flood event at community level include perfect communication at community level and selection of makeshift settlement. Proper assessment of flood risk in urban areas is still challenging simply because of its complexity as compared to situation in rural areas. Common flood risk analyses do not usually incorporate social and ecological impacts but exclusively assess economic damages, which can be measured in monetary terms (Haque et al. 2012). Comprehensive approaches which try to integrate economic, ecological, and social impacts are less available (Schanze 2006). Particularly, the latter are frequently omitted due to a lack of suitable data.

There are many studies with different conceptual frameworks for flood vulnerability, risk assessment, and adaptation. For instance, Oculi and Stephenson (2018) observed that one of the earliest "frameworks" of adaptation were based on three attributes: climatic-stimuli, the system that is adapting, and method of adaptation. They also recognized that adaptation strategies can be grouped by timeframe of interest, types of behavior, sector, scale, and level of governance. Adaptation to extreme events such as flood is vital in the present era due to the multifaceted nature of the causes and effects, which is exacerbated due to the increasing population and climate change. The ever-changing and cross-boundary nature of flood risk renders adaptation strategies as very crucial in this period of fluctuating social and environmental conditions (Jongman 2018). Flood adaptation strategies are often intended to minimize impacts on various sectors such as built environment, human health, water quality, and transport infrastructures (Wilby and Keenan 2012). The efficient and effective adaptation strategies should have the services and facilities to slow flood waters; use nature-based solutions, early warning systems, and financing schemes to tackle and reduce the economic loss; and practice risk-informed land planning (Jongman 2018).

\section{Observing the Nature of Flood Risk Situation in Kano City}

The sites observed in this chapter are located in Dala Local Government Area (LGA), which is the nucleus of the ancient Kano city in northern Nigeria. It is named after the Dala, a residual hill which is the original site from which the city emerged since prehistoric times. The area is located around between latitude $12^{\circ} 00^{\prime}$ $00^{\prime \prime} \mathrm{N}$ to $12^{\circ} 03^{\prime} 21^{\prime \prime} \mathrm{N}$ and Longitude $8^{\circ} 27^{\prime} 30^{\prime \prime} \mathrm{E}$ to $8^{\circ} 31^{\prime} 40^{\prime \prime} \mathrm{E}$. (Fig. 1). This LGA covers a total land area of about $19 \mathrm{~km}^{2}$ and total population of 415,777 as of 


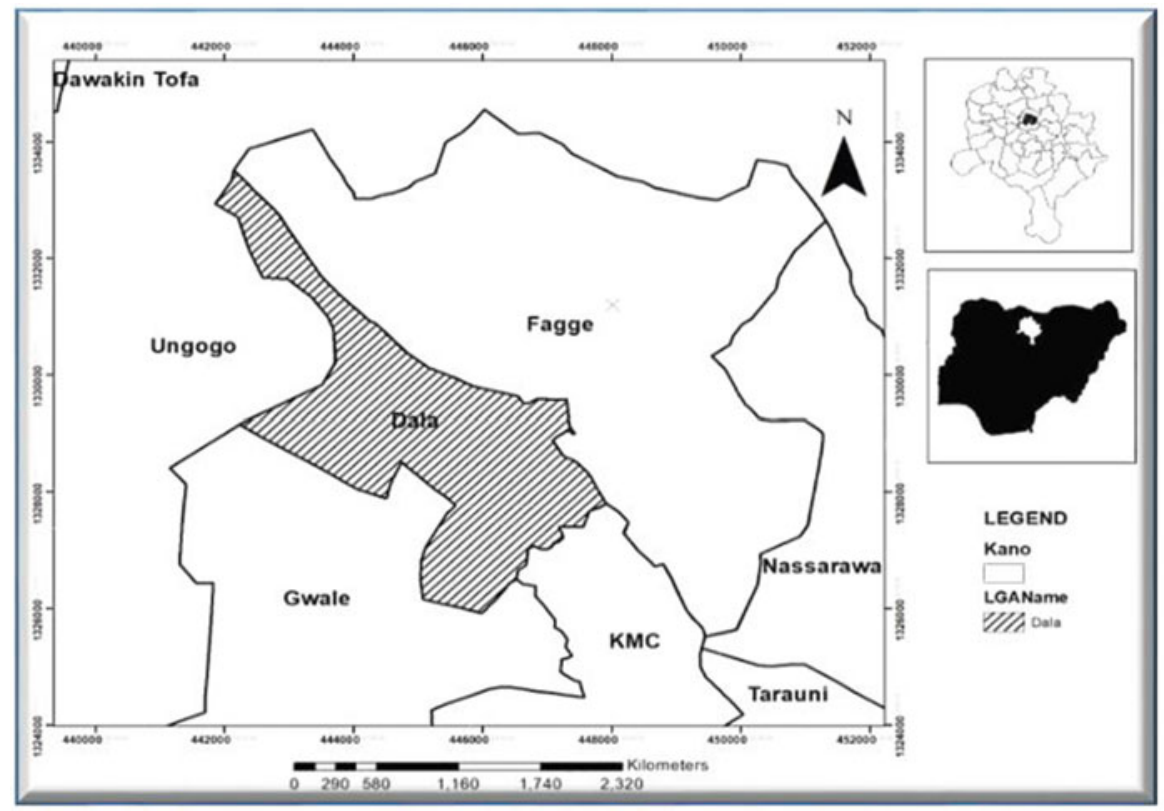

Fig. 1 Map of urban Kano showing the location of Dala Local Government Area

2006 national population and housing census. There was significant increase in the natural population in the state and the study area. The natural increase was estimated to have risen from $2.51 \%$ in 1960 s to $3.3 \%$ in 1980 s and $4.5 \%$ till date, although the urban growth rate is about 5.5\% annually (Mustapha et al. 2014). This implies that the area is a high density core urban settlement and given its nature of terrain is vulnerable to flooding. Previous studies suggested the importance of socioecological systems in understanding the urban environment in Kano (Barau et al. 2013).

\section{Relief and Geology}

Relief of the state is said to be $80 \%$ of composed basement which comprises of marbles, granites, and gneisses (Salami et al. 2016). Jakara River is underlain by crystalline Basement complex of pre-Cambrian origin which losses its identity by disappearing into the Chad Formation. Crystalline basement of pre-Cambrian forms the underline of River Jakara, made up of granites extending to Gabasawa toward East and Yadai toward North. This river serves as the natural drain in the study which collects runoff from different tributaries. This geological setting suggests that the study area is susceptible to flood based on its largely impervious surface. 


\section{Climate and Hydrology}

The climate of the state is tropical wet and dry type according to Koppen's classification, although climatic changes are believed to have occurred in the past. The climate features in Kano as a whole are typical of West African savannah. Temperature in the region is generally high all year round, together with gradual increase every season. It can be said to be higher usually from January to April which may reach as high as $43{ }^{\circ} \mathrm{C}$, respectively (Mustapha et al. 2014). According to Sanni and Okhimamhe (2009), the annual rainfall values are unpredictable from 1 year to another. For instance, 1999, 2004, 2010, and 2012 witnessed highest annual values in both temperature and rainfall, that is to say, above normal, compared to previous years.

\section{Research Data}

Primary data were collected using questionnaire, field observations, field surveys, and in-depth interview. The questionnaires were administered to household heads and/or adult respondents in each residence that were within the $100 \mathrm{~m}$ radius of flood-prone areas. This strategy enabled the researchers to identify factors that exacerbate flooding and types of response undertaken to lessen flood risk. Initially, the authors worked with communities to identify the flood hotspots in addition to observations made during previous flood events in the study area.

Global Positioning System (GPS) was used during field survey to take the coordinates of the flood-prone areas which was later imported into the Google Earth for spatial representation of the flood prone areas which was also used in generating the Digital Elevation Model (DEM) and contour map of the study area to analyze vividly the nature of terrain as well as contour of the study area. ArcGIS 10.4 was used to generate the location map and flood-prone areas respectively. Google Earth was used to produce the satellite imagery which was used for spatial representation, while interview was used to source institutional responses to flood risk in the study area, respectively. Interview was conducted in State Emergency Relief and Rehabilitation Agency (SERERA) and Kano State Urban Planning and Development Authority (KNUPDA) with key informant on flood risk and adaptation measures in the study area. This further aid in determining the extent to which these institutions respond to flooding.

Secondary data was sourced through searching the keywords with the aid of Google Scholar (i.e., flood, risk, flood risk, adaptation, and adaptation measures) from scholarly peer-reviewed journals, books, and government archive which provided proper understanding of the research problem at local and global level. The information sourced provided an insight to the researcher on flood risk, flood impacts, its causes, as well as factors that exacerbate flooding.

The questionnaire was administered to the seven (7) flood-prone clusters (462 houses) which include Kofar Ruwa, Kwanar Taya, Gwammaja, Babban Layi, behind Filin Dantata, Lunkwi, and adjacent Gidan Baban Gwari, respectively. Two 
hundred and seventeen (217) copies of questionnaires were randomly distributed to the residents within 100 meter radius of each flood-prone area (31 for each zone for equal and unbiased representation) using the simple random sampling techniques. However, only one hundred and ninety six (196) copies of the distributed questionnaires were retrieved due to loss and failure to fill by the residents. Questions asked were tailored toward identification of causes of flood, factors that exacerbate flooding, as well as resident adaptation measures to flood risk in the study area. In addition, data related to demography and socioeconomic characteristics were also captured. The sampling size adopted for this study was determined using Taro Yamane's formula (1967) with 95\% confidence level. The formula is given as

$$
\mathrm{n}=\frac{N}{1+N(e) 2}
$$

where

$n=$ Sample size required

$N=$ Number of population in which the sample will be drawn (462 houses)

$e=$ Margin of error, given as 0.05

$1=$ Constant.

$$
\mathrm{n}=\frac{462}{1+462(0.05)^{2}}
$$

$n=214.3851508121 / 7=30.626450116$. (Akukwe 2014)

After calculating the sample size by substituting the number of dwelling units (462) into the Yamane formula, the number of sample was 214.3851508121 houses. Dividing this number by the number of flood-prone areas (7) yielded 30.626450116 houses respectively. Therefore, in order to obtain a reliable data, researcher rounded up the sample size to 31 dwellings per each flood-prone area (Fig. 2). Thus, a total of 217 sample size emerged out of 462 sample frame. For convenience and transparency, nine (9) variables were used which include heavy rainfall, poor drainage facilities, slope and topography of the area, dumping of refuse in drainages, blockage of drainage channels, impervious surface, absence of drainage channels, and unplanned development along floodplains. The targeted respondents on a normal circumstances were the household heads, but in a scenario where the household heads were not around, an adult respondent from each dwelling was selected to fill in the required questions based on 5-point Likert scale from Strongly Agree $(\mathrm{SA}=5)$ to Strongly Disagree $(\mathrm{SD}=1)$. This procedure was adopted from a study conducted by Devkota et al. (2014).

Institutional responses were obtained through an in-depth interview with key informants from Kano State Emergency Relief and Rehabilitation Agency (SERERA) and Kano State Urban Planning and Development Authority (KNUPDA). In SERERA, the interview was oriented toward past flood damages, 


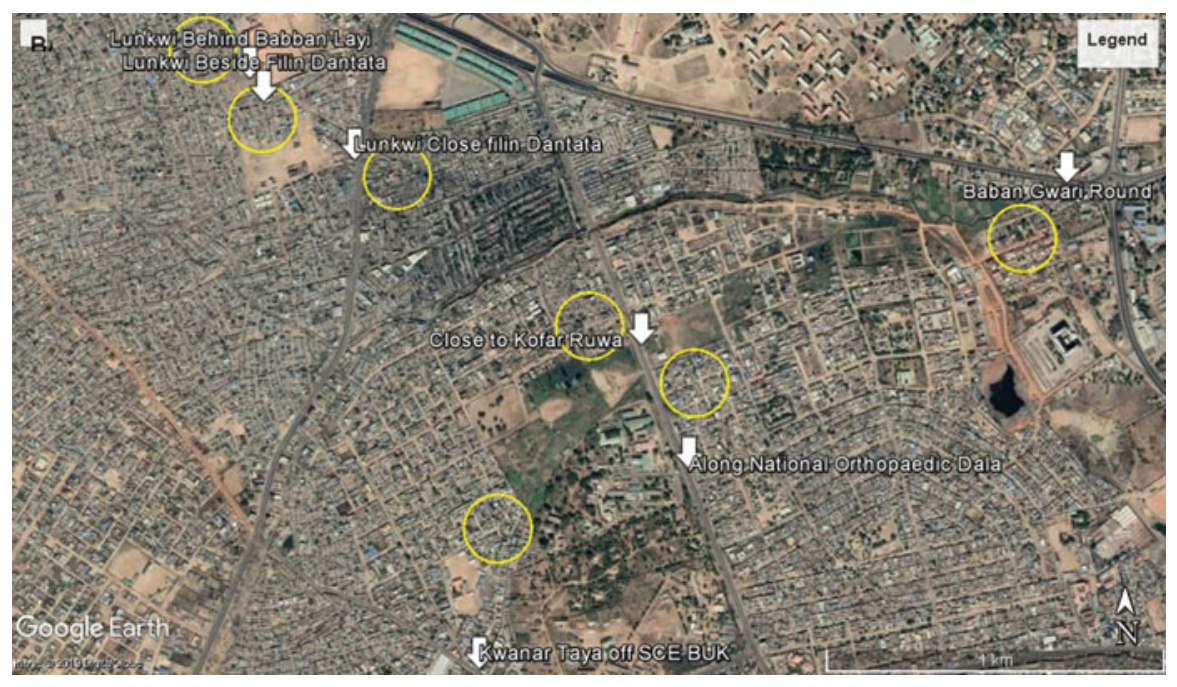

Fig. 2 Google image showing flood-prone areas and houses within the $100 \mathrm{~m}$ radius of each other. (Source: Authors' Field Survey 2019)

existing adaptive measures to respond to flood hazard for pre-, during, and postflood events. This information was relevant to the study because it helped in determining the extent to which the stipulated hazard in the study area was responded to. In KNUPDA, issues raised were concerning planning regulations around the flood-prone areas. This information was relevant to the study because it further helped the researchers to bring out the level of compliance (public) to adapt to the problems of flood-prone area or otherwise. In all the cases, the interview was recorded (with permission of respondents) using phone audio recorder, which was subsequently transcribed to a verbatim record.

Five-point Likert scale and weighted average index (WAI) on the basis of "Highly Applicable" to "Very Less Applicable" were used for analysis of the questionnaire. The first part of the questionnaire was demographic and socioeconomic information of the respondents. These were analyzed using SPSS, and the results were represented in simple tables, charts, and graphs. ArcGIS 10.4 and Surfer software were used to draw and analyze the digital elevation model and contour map of the study area. While community responses were collected before, during, and after flooding by the public were analyzed using weighted average index (WAI) against a scale of 1 to 5 . The adaptation strategies for each respondent were rank based on the weighted average index (WAI) which is given as

$$
\begin{gathered}
\mathrm{WAI}=\frac{\mathrm{F} 1 \times \mathrm{W} 1+\mathrm{F} 2 \times \mathrm{W} 2+\mathrm{F} 3 \times \mathrm{W} 3+\mathrm{F} 4 \times \mathrm{W} 4+\mathrm{F} 5 \times \mathrm{W} 5}{\mathrm{~F}_{1}+\mathrm{F}_{2}+\mathrm{F}_{3}+\mathrm{F}_{4}+\mathrm{F}_{5}} \\
\mathrm{WAI}=\frac{\sum f i \times \mathrm{W} i}{\sum \mathrm{fi}}
\end{gathered}
$$


where

$\mathrm{F}=$ frequency of the respondents

$\mathrm{W}=$ weight of each scale

$\mathrm{i}=$ weight

Note $(5=$ highly applicable, $4=$ applicable, $3=$ moderately applicable, $2=$ less applicable and $1=$ very less applicable) (Devkota et al. 2014). This generated the measures and/or strategies that were mostly applicable and least applicable by the respondents in the study area.

\section{Digital Elevation Model (DEM) of the Study Area}

The digital elevation model (DEM) as illustrated in Fig. 3 revealed the elevation of the study area from which the blue shades represent the areas with the highest elevation 520-525 $\mathrm{m}$ above sea level (Dala hill), while the green represents the areas with the lowest elevation $470-475$ in the study area respectively. These green shades on the DEM represent the locations of the flood-prone areas. It is apparent that after rainfall the stormwater radiates in a centrifugal direction reaching the lowest elevation (flood prone areas) as natural drains. However, as built-up areas, they easily become flooded.

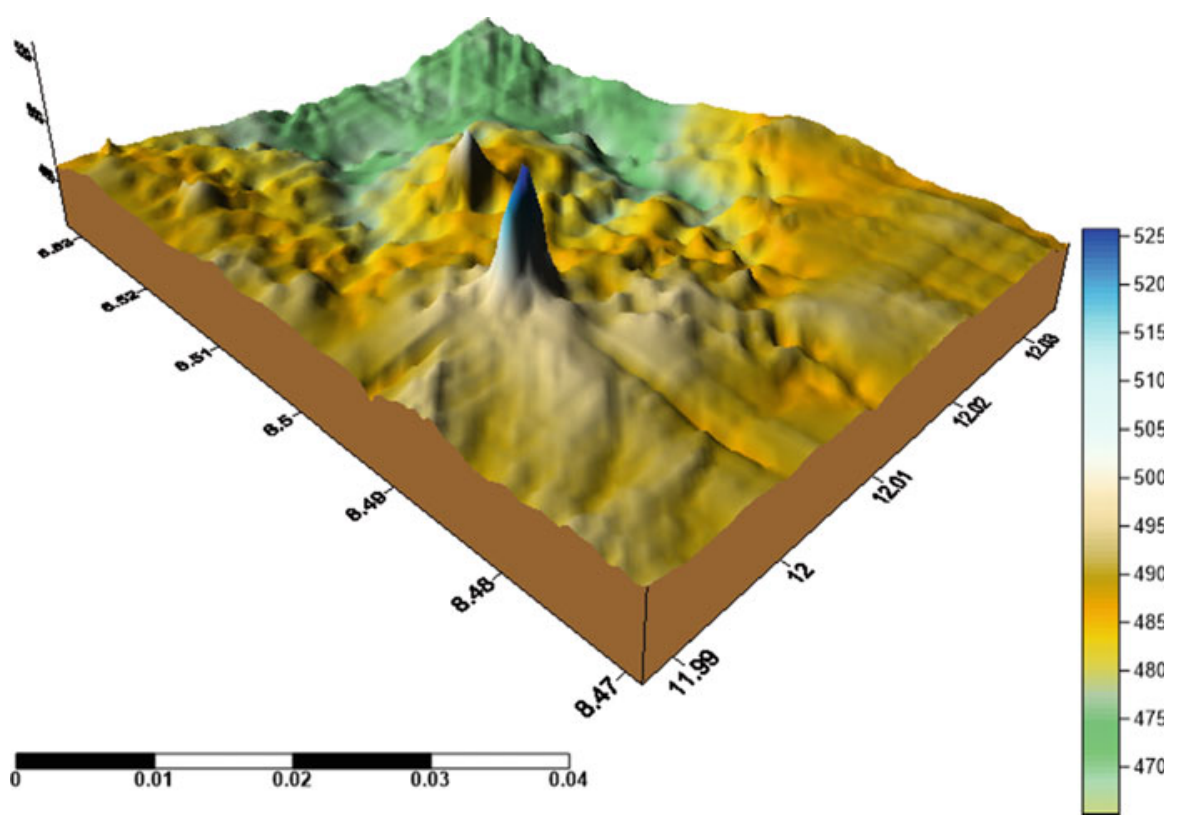

Fig. 3 Digital elevation model (DEM) of the study area showing variation of elevation 
Fig. 4 Contour map of the study area. The lighter spots depict areas with highland, while the darker spots represent areas with low land

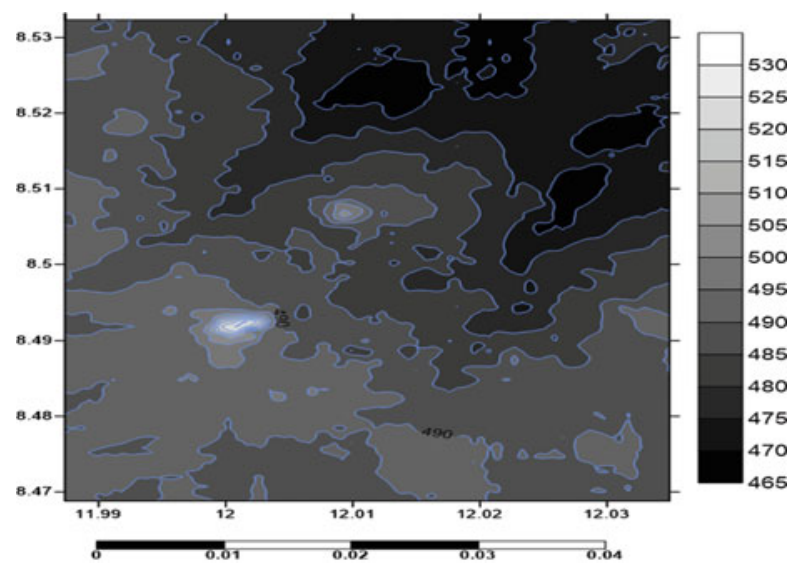

The green shades represent lowlands, while the blue shades represent highland areas (Dala hill) in the study area.

On the other hand, the contour map (Fig. 4) illustrates the variation of elevation of the study area. The white portion represents the point with the highest elevation $(530 \mathrm{~m})$, while the dark portion represents the points with lowest elevation $(465-470 \mathrm{~m})$. From these, it can be deduced that elevation still determines floodability of even highly urbanized areas.

\section{Socioeconomic Characteristics of the Residents}

The tendency of flood risk is not the same for all people although all may be situated in a flood-prone areas. It varies considerably with demographic and social characteristics. Although flood risk presents significant health burden worldwide, socioeconomic status is closely related to being flooded or otherwise (Aerts et al. 2018). This section explains the socioeconomic characteristics of the residents in the study area which cover residence, gender, age, marital status, educational level, occupation, average monthly income, housing condition, and construction material used.

\section{Socioeconomic Characteristics of the Respondent in the Study Area}

Table 4 revealed the respondent residential locations of the respondents out of which (28) 14.3\% were from Kofar Ruwa, (26) 13.3\% from Kwanar Taya, (30) 15.3\% from Gwammaja, (27) 13.8\% from Babban Layi, (29)14.8\% from behind Filin Dantata, (30) 15.3\% from Lunkwi, and (26) 13.3\% from Gidan Baban Gwari which constitute the sum of 196 respondents. Gender is another important variable in any research of this nature. The gender distribution of respondents revealed dominance of male 
respondents. Male respondents featured more than female as they dominate household headship. Again their female counterparts were not freely available to interact with researchers due to cultural barriers in the study area. In general, there is an indication that majority of the respondents are still in their active and productive age. Age is an important attribute that helps in understanding people's perception about a given phenomenon. And with regard to flood risk and adaptation, it helps in improving the methods to be used in adapting to risk as well as mitigating its impact.

The perception and attitudes of an individual due to marital status may differ; findings presented in Table 4 showed the dominance of married respondents in the study area. In addition, marital status is relevant to the study because married people will be more willing to initiate coping strategies in trying to reduce potential losses than the unmarried population simply because they are more attached to the community, and it is assumed that each married person has apartment which is in the long run liable to flood risk. Household size is important to understand socioeconomic status and vulnerability of households. In this context, it is assumed that the larger the household size, the more is the risk of losing more lives and/or property and vice versa.

Knowledge influences reasoning, attitudes, and understanding of individuals from a given social phenomenon. The findings presented in Table 4 also outlined respondents' level of education where (71) $36.2 \%$ has tertiary education and (53) $27.0 \%$ with informal education, while (59) $30.1 \%$ and (13) $6.6 \%$ were having only secondary and primary level of education, respectively. This is an indication that majority of the respondents were literate and thus capable of providing adequate and relevant information with regard to flood risk and adaptation measures in the study area.

Occupation or livelihood is another important factor of consideration as it determines people's choice of residence. Thus, the social class of individuals determines their area of residence. It has been established that the more comfortable and secured areas of residence are occupied by the richer households while the less privileged are left with the marginal areas (Salami et al. 2016). In addition, income is an important determinant which is congruent with income and occupation. The situation in the study area in relation to income further highlights what is known with regard to the poor who occupy areas associated with unplanned urban growth and substandard informal settlements on floodplains among other things (Salami et al. 2016).

Age of building is another important determinants of consideration simply because building has a lifespan just like humans. Buildings deteriorate with time and thus become more exposed to destructive flood impacts. Findings revealed that with exclusion of some buildings among which are Government Girls College, Dala, and National Orthopaedic Hospital majority of the buildings in the area have undergone transformation. This implies that majority of the buildings were constructed not so long, thus a concrete evidence of recent encroachment on open spaces and changes in building materials. Building materials play important role in proofing water absorption. Such changes in urban morphology are said to have increased flood events in urban Kano which covers the study area (Barau 2015) (Table 1). 
Table 1 Showing frequency and percentage response on the socioeconomic characteristics of the respondent

\begin{tabular}{|c|c|c|}
\hline Gender & Frequency & Percent \\
\hline Male & 150 & 76.5 \\
\hline Female & 46 & 23.5 \\
\hline Total & 196 & 100.0 \\
\hline \multicolumn{3}{|l|}{ Age } \\
\hline $18-25$ years & 57 & 29.1 \\
\hline 26-32 years & 51 & 26.0 \\
\hline $33-39$ years & 54 & 27.6 \\
\hline 40 years and above & 34 & 17.3 \\
\hline Total. & 196 & 100.0 \\
\hline \multicolumn{3}{|l|}{ Marital status } \\
\hline Single & 90 & 45.9 \\
\hline Married & 106 & 54.1 \\
\hline Total & 196 & 100.0 \\
\hline \multicolumn{3}{|l|}{ Household size } \\
\hline $0-4$ & 82 & 41.8 \\
\hline $5-9$ & 52 & 26.5 \\
\hline $10-14$ & 49 & 25.0 \\
\hline 15 and above... & 13 & 6.6 \\
\hline Total & 196 & 100.0 \\
\hline \multicolumn{3}{|l|}{ Occupation } \\
\hline Civil servants & 32 & 16.3 \\
\hline Traders & 97 & 49.5 \\
\hline Farmers & 21 & 10.7 \\
\hline Others & 46 & 23.5 \\
\hline Total & 196 & 100.0 \\
\hline \multicolumn{3}{|c|}{ Average monthly income } \\
\hline$<20,000$ & 63 & 32.1 \\
\hline $20,000-40,000$ & 49 & 25.0 \\
\hline $40,000-60,000$ & 36 & 18.4 \\
\hline 60,000 and above & 21 & 10.7 \\
\hline Total & 196 & 100.0 \\
\hline \multicolumn{3}{|l|}{ Age of building } \\
\hline $0-5$ years & 46 & 23.5 \\
\hline $5-10$ years & 78 & 39.8 \\
\hline $10-15$ years & 41 & 20.9 \\
\hline 15 years and above & 31 & 15.8 \\
\hline Total & 196 & 100.0 \\
\hline \multicolumn{3}{|c|}{ Building construction material } \\
\hline Mud & 40 & 20.4 \\
\hline Cement block & 154 & 78.6 \\
\hline Bamboo & 0 & 0 \\
\hline Others & 2 & 1 \\
\hline
\end{tabular}


Table 1 (continued)

\begin{tabular}{l|l|l}
\hline Gender & Frequency & Percent \\
\hline Total & $\mathbf{1 9 6}$ & $\mathbf{1 0 0 . 0}$ \\
\hline Condition of buildings & \multicolumn{2}{|l}{} \\
\hline Need minor repair & 101 & 51.5 \\
\hline Need major repair & 39 & 19.9 \\
\hline In good condition & 56 & 28.6 \\
\hline Total & $\mathbf{1 9 6}$ & $\mathbf{1 0 0 . 0}$ \\
\hline
\end{tabular}

\section{Public Perception and Current State of Flood Risk and Adaptation}

Adaptation may include modifying susceptibility, increasing response capacity, and reducing exposure (Merz et al. 2010); thus, this section focused on community perception of flood risk, vulnerability profiles of the households regarding flood experience, as well as the residents' adaptation (coping) mechanisms against flood risk (i.e., actions taken by the public prior to, during, and after flood event) in the study area. Questionnaire survey was used to assess the level of flood severity and whether or not affected previously. The following parameters "severely affected," "affected but not severe," and/or "not affected at all" were used in generating this information which revealed that (68) $34.7 \%$ of the respondents were not affected at all, (91) $46.4 \%$ were affected but not severe, while (37) $18.9 \%$ of the respondents were severely affected by previous flood havoc in the study area. In order words, it can be deduced that $65.3 \%$ of the sampled population were affected by flood disaster in the study area (Fig. 5).

The factors that cause and exacerbate flooding in the study area based on the outcome of the current study include heavy rainfall, dumping of refuse on drainages, as well as blockage of drainage among others as shown in Table 2. These factors were ranked based on average mean score $(\mathrm{X})$ of each factor and sum weighted value (SWV) of responses derived from questionnaires.

Findings as presented in Table 2 established that the indicator with the highest rating is rainfall with a weighted value of 4.77 and a positive deviation of 0.82 from the mean, while the least rated indicator was impervious surfaces with a weighted value of 3.08 and a negative deviation of -0.87 from the mean, respectively. This denotes that heavy rainfall is the major cause of flood in the study area. Thus, climate change appears to be a major factor and driver of flooding incidents in urban areas of developing countries. Therefore, it is imperative for urban areas to embrace priority action to tackle climate change both as local and global challenge (Bai et al. 2018). The study further revealed that out of the nine indicators used, five had a positive deviation which are the major causes of flooding in the study area, while four had a negative deviation from the mean. The indicators with positive deviation about the mean include heavy rainfall (with a weighted value of 4.77 and a positive mean of 0.82 ), dumping of refuse and/or waste on drainages (with a weighted value of 4.42 and a positive mean of 0.47 ), slope and topography of the area (with a weighted 


\section{Spatial Distribution of Flood Prone Areas}

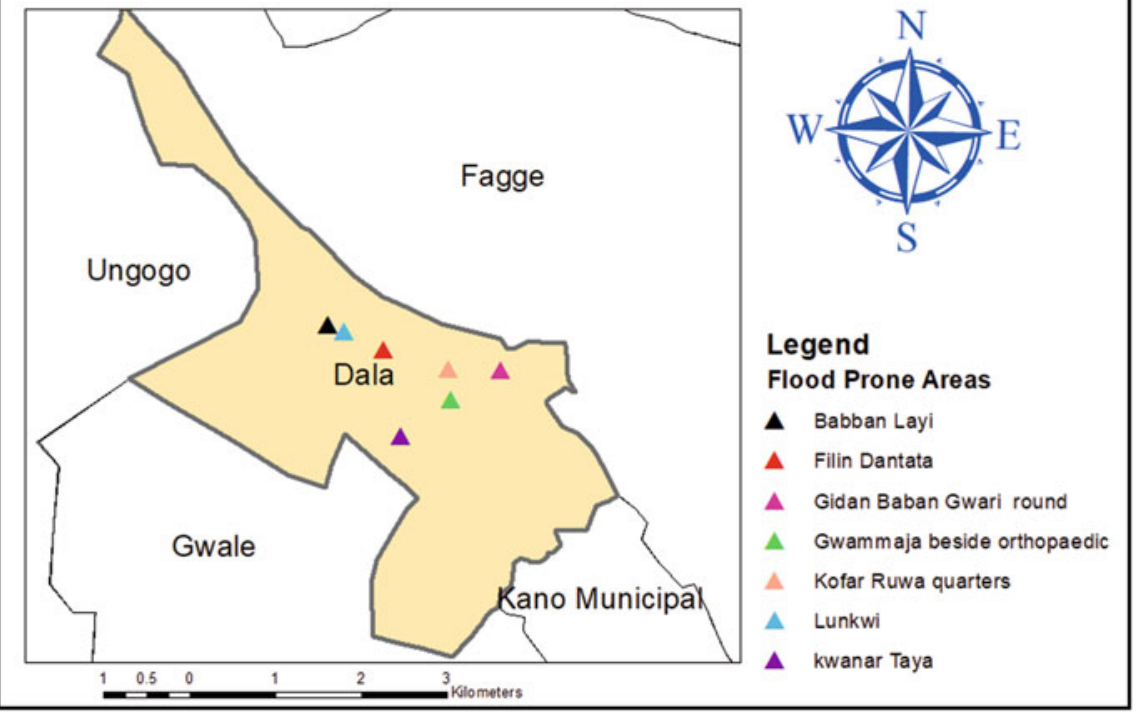

Fig. 5 Spatial distribution of the flood-prone areas in Dala LGA. (Source: Author 2019)

Table 2 Causes of flood in the study area with their ranks in descending order

\begin{tabular}{l|l|l|l|l|l|l|l|l|l}
\hline Causes & SA & $\mathrm{A}$ & $\mathrm{U}$ & $\mathrm{D}$ & $\mathrm{SD}$ & $\mathrm{SWV}$ & $\mathrm{X}$ & $\mathrm{X}-\mathrm{X}$ & Ranks \\
\hline Heavy rainfall & 154 & 40 & 0 & 2 & 0 & 934 & 4.77 & 0.82 & 1 st \\
\hline $\begin{array}{l}\text { dumping of waste/ } \\
\text { refuse on drainages }\end{array}$ & 110 & 70 & 4 & 12 & 0 & 866 & 4.42 & 0.47 & 2 nd \\
\hline $\begin{array}{l}\text { Slope and topography } \\
\text { of the area }\end{array}$ & 86 & 66 & 22 & 20 & 2 & 802 & 4.09 & 0.14 & 3 rd \\
\hline $\begin{array}{l}\text { Blockage of drainage } \\
\text { channels }\end{array}$ & 82 & 77 & 9 & 21 & 7 & 794 & 4.05 & 0.1 & 4 th \\
\hline $\begin{array}{l}\text { Poor drainage } \\
\text { facilities }\end{array}$ & 79 & 69 & 26 & 22 & 0 & 793 & 4.05 & 0.1 & 5 th \\
\hline $\begin{array}{l}\text { Unplanned } \\
\text { development along } \\
\text { flood plain }\end{array}$ & 40 & 97 & 41 & 15 & 3 & 744 & 3.80 & -0.15 & 6 th \\
\hline $\begin{array}{l}\text { Absence of drainage } \\
\text { channels }\end{array}$ & 63 & 64 & 28 & 37 & 4 & 733 & 3.74 & -0.21 & 7 th \\
\hline Soil type & 11 & 72 & 68 & 38 & 7 & 630 & 3.21 & -0.37 & 8 th \\
\hline $\begin{array}{l}\text { Impervious surface } \\
\text { Total }\end{array}$ & 26 & 41 & 77 & 26 & 26 & 603 & 3.08 & -0.87 & 9 th \\
\hline
\end{tabular}

Source: Authors' Field Survey

Note: SA (5) = STRONGLY AGREE, A (4) = AGREE, U (3) = UNDECIDED, D (2) = DISAGREE, SD (1) = STRONGLY DISAGREE, SWV = Sum of Weighted Value, $\mathbf{X}=$ Mean score. $\overline{\mathbf{X}}=$ Mean deviation 


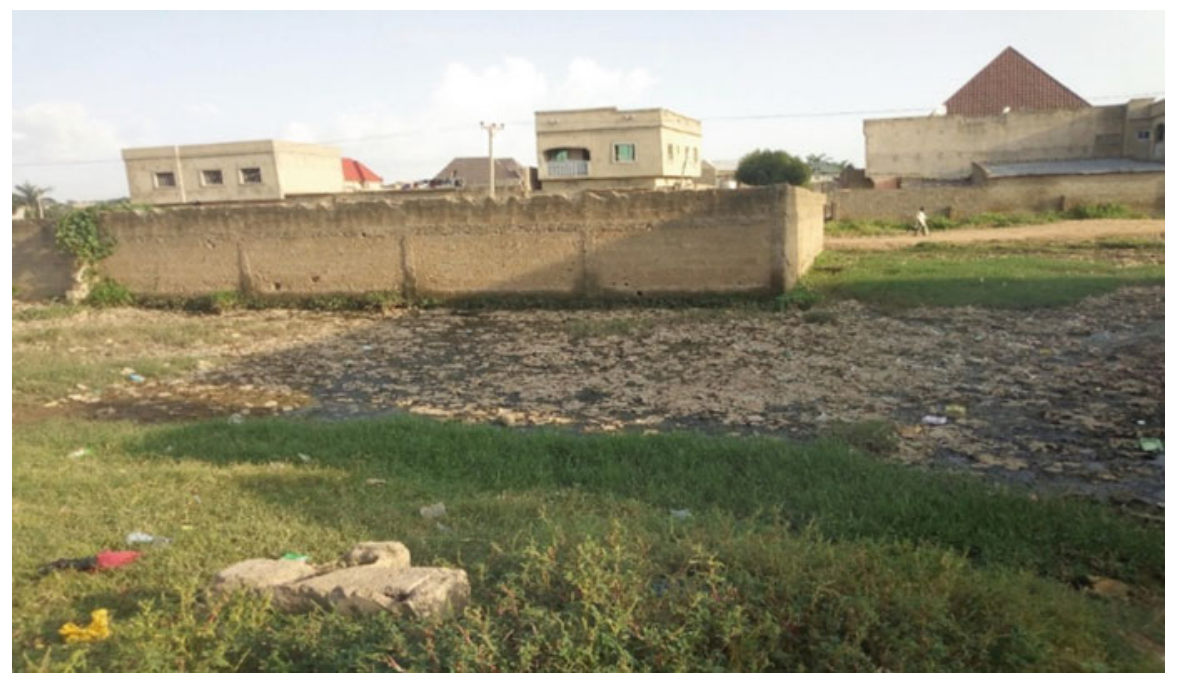

Fig. 6 Abandoned development in a low-lying area due to adverse effect of flooding in the study area (Kofar Ruwa quarters). (Source: Field Survey 2019)

value of 4.09 and a positive mean of 0.14), blockage of drainage channels (with a weighted value of 4.05 and a positive mean of 0.1 ), and poor drainage facilities (with a weighted value of 4.05 and a positive mean of 0.1 ). On the other hand, the indicators with negative deviation about the mean were unplanned development along floodplains (with a weighted value of 3.80 and a negative mean of -0.15 ), absence of drainage channels (with a weighted value of 3.74 and a negative mean of -0.21 ), soil type (with a weighted value of 3.21 and a negative mean of -0.37 ), and impervious surface (with a weighted value of 3.08 and a negative mean of -0.87).

The results presented here highlight the importance of socioecological dimensions of flooding because of close and tangential relations between human and naturally induced drivers of climate change, landscape, ecology, and infrastructural development. It is equally important to recognize that the impact of human transformation of landscape and/or misuse of infrastructure galvanize negative effects of climate change in the society. For instance, as evident from Figs. 6, 7, and 8, people erect structure in areas where the morphology is not favorable, and hence flood waters cause destruction to buildings (Fig. 6). On the other hand, indiscriminate dumping of waste causes siltation and sedimentation of waterways which cause flooding in the study area (Figs. 7, 8, and 9). In other words, people need to be educated and informed about climate change as it is obvious that level of education does not sufficiently make people more informed. Hence, it is critical to follow multiple strategies of educating and communicating climate change to the public (Barau and Tanko 2018). 


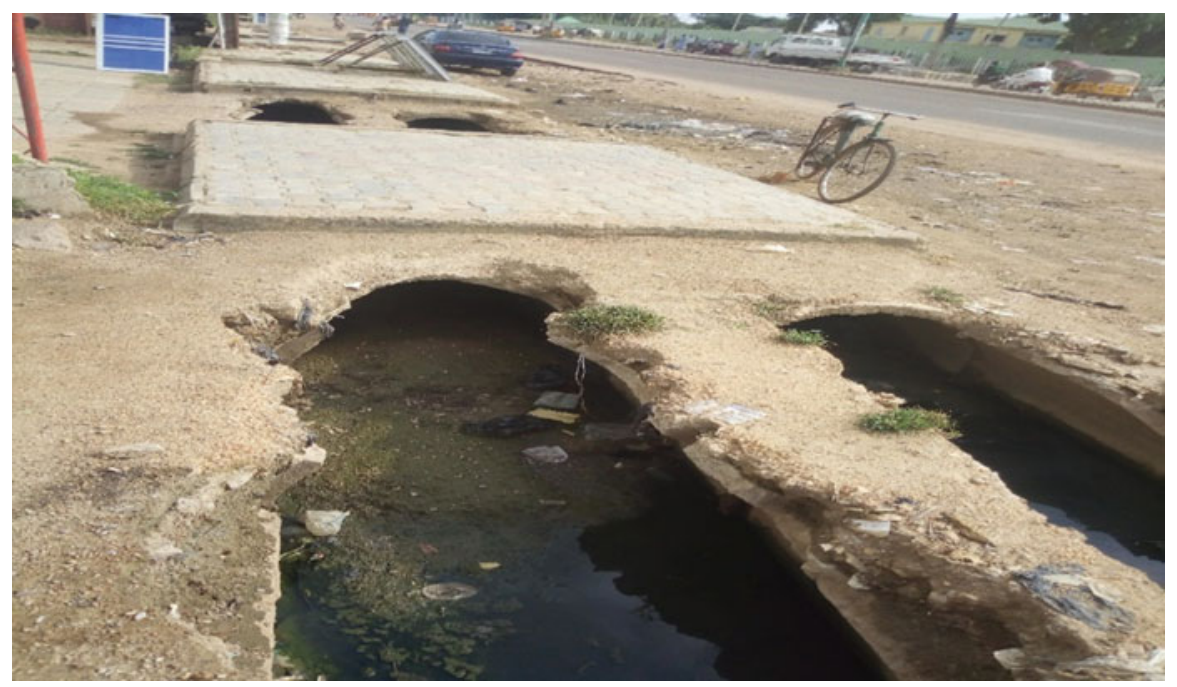

Fig. 7 Poor drainage filled up with silt, obstructing the free flow of storm water along Dala Orthopaedics Gwammaja. (Source: Field Survey 2019)

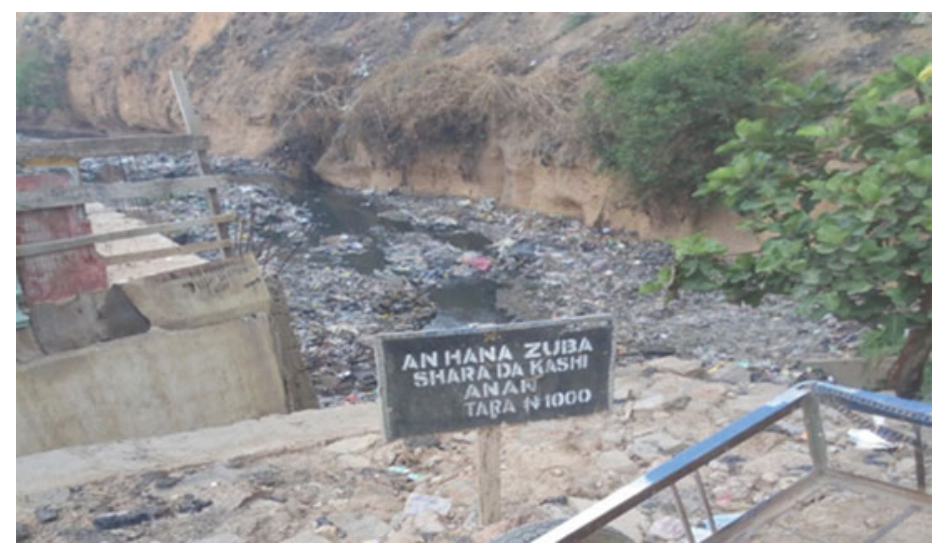

Fig. 8 Indiscriminate dumping of waste along drainage in the study area. (Source: Field Survey 2019)

\section{Public and Institutional Adaptation Response to Floods in the Study Area}

Public and institutional response to flood risk is one of the objectives of the study. Here, public response to flood risk was collected through observation and questionnaire survey, while the institutional response was collected through an interview with key informants in the specified planning and environment agencies. Firstly, with 


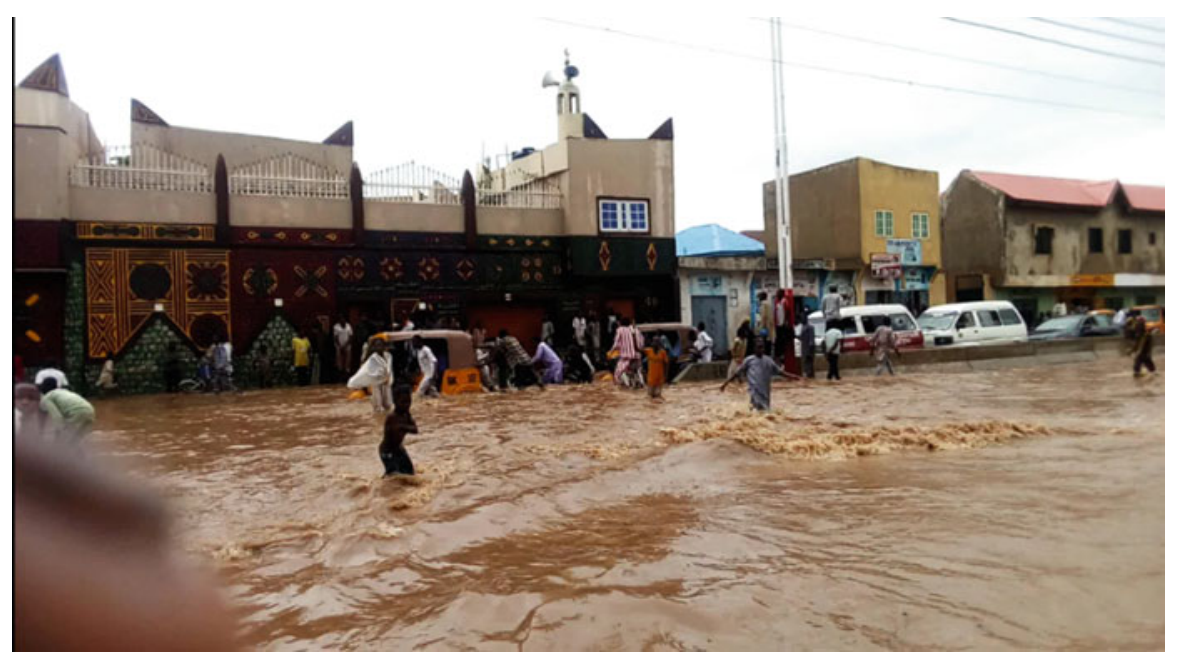

Fig. 9 Area submerged during the 2019 flood in Kwanar Taya. (Source authors' field work 2019)

regard to people's effort to prevent flood risks which some researchers called it do-ityourself (DIY) adaptation (Udelsmann Rodrigues 2019), a field survey revealed that the residents of the study area also employed this strategy through the use of sand bags, raising of walls, and de-siltation among others to divert flood water away from their residential area (community), and this was specifically observed in Gwammaja besides Dala National Orthopedics Hospital and also at Kwanar Taya which is another section of the study site. All these efforts represent the community's local responses to reduce potential harm and adverse effects of flood incidents. However, due to uncertainty of rainfall and anthropogenic factors that induce the floods, the community members can hardly achieve complete defense of their locality as it is beyond their capacity to prevent floods. This situation remarkably improve our understanding of the DIY adaptation efforts and at the same time the indispensability of municipalities to support the efforts of vulnerable communities particularly those inhabiting marginal areas that are more exposed to climate change.

The study further revealed that most of these areas that were subjected to frequent flood hazard have developed different flood risk management approaches for pre-flood, during, and post-flood period. Table 3 outlines the residents' coping strategies undertaken before flood/rainy season. Clearing of waterways appeared to be the first with WAI of 4.45 and followed by de-siltation as the second most practiced strategy with WAI of 3.77; widening of drainage channels was ranked third with WAI of 3.51, and producing human resource/trained manpower was ranked fourth with WAI of 3.48. Likewise use of metal sheeting and/or sandbag was ranked fifth with WAI of 3.26, while sharing of contact information was ranked sixth with WAI of 2.86 as the least strategy practiced in the study area, respectively.

The current study has further revealed that community adaptation planning is undertaken at various scales reflecting, in particular, the seasonality of rainfall. For 
Table 3 Pre-flood adaptation strategies at community level $(\mathrm{N}=196)$

\begin{tabular}{|c|c|c|c|c|c|c|c|c|c|c|}
\hline Response & HA & A & MA & LA & VLA & SMV & $\begin{array}{l}\text { WAI } \\
(\bar{X})\end{array}$ & $X$ & $(\bar{X}-\mathrm{X})$ & Ranks \\
\hline $\begin{array}{l}\text { Clear water } \\
\text { ways to } \\
\text { remove dirt }\end{array}$ & 128 & 41 & 21 & 0 & 6 & 873 & 4.45 & \multirow[t]{7}{*}{3.56} & 0.89 & $1 \mathrm{st}$ \\
\hline De-siltation & 38 & 115 & 21 & 3 & 19 & 738 & 3.77 & & 0.21 & 2nd \\
\hline $\begin{array}{l}\text { Share } \\
\text { contact } \\
\text { information }\end{array}$ & 15 & 53 & 41 & 63 & 24 & 560 & 2.86 & & -0.7 & 6th \\
\hline $\begin{array}{l}\text { Produce } \\
\text { trained } \\
\text { manpower }\end{array}$ & 44 & 60 & 56 & 19 & 17 & 638 & 3.48 & & -0.08 & 4th \\
\hline $\begin{array}{l}\text { Widened } \\
\text { drainage } \\
\text { channels }\end{array}$ & 26 & 106 & 27 & 16 & 21 & 688 & 3.51 & & -0.05 & $3 \mathrm{rd}$ \\
\hline $\begin{array}{l}\text { Use of } \\
\text { metal } \\
\text { sheeting/ } \\
\text { sandbags }\end{array}$ & 25 & 84 & 37 & 17 & 33 & 639 & 3.26 & & -0.3 & 5 th \\
\hline Total & 276 & 459 & 203 & 118 & 304 & 4136 & 21.33 & & & \\
\hline
\end{tabular}

Source: Author's Field Survey 2019

Note: $\mathbf{H A}=$ Highly Applicable, $\mathbf{A}=$ Applicable, $\mathbf{M A}=$ Moderately Applicable, $\mathbf{L A}=$ Less Applicable, VLA = Very Less Applicable, WAI $=$ weighted Average Index, SMV $=$ sum of mean variable

instance, among the 196 respondents, 128 (63.5\%) stated that clearing of drainages in anticipation of rainy season was a highly considered strategy for improving the drainage capacity and its functionality. This strategy was regarded as the most relevant flood risk adaptation strategy in the study area which is followed by $115(58.7 \%)$ of the respondent that mentioned de-siltation as the next most important adaptation strategy that is used in the community (see Table 3). Again, it is important to note that local governments have actually failed in delivering their responsibility of environmental upkeep which can be carried out through increased financing and enforcement environmental and sanitary provisions. In other words, while the DIY role played by the communities is commendable, the total neglect of vulnerable communities is deplorable. In the interest of environmental justice and social equality and inclusion, it becomes imperative on local governments in developing countries to consider integrated and larger adaptation strategy that will tackle community level vulnerabilities and strategic efforts such as DIY as a means of achieving an inclusive adaptation to flood risk. The need to focus on flooding is very important as it has been identified as universal issue in global climate change risk which affects more people than any other form of disaster (Nkwunonwo et al. 2016; Salami et al. 2016). 


\section{Flood Adaptation Strategies at Community Level}

The above subsection dwelt on pre-flood DIY efforts, while Table 4 in this subsection shows the residents' coping strategies during flood/rainy season based on applicability of various adaptation strategies. According to the outcome of the survey, selection of safer place to stay was ranked first (most applicable) in the study area with 3.85 WAI. Whereas relocation to the nearest neighborhood until after rainfall was second with 3.82 WAI, the third most applicable strategy was taking care of the children, the aged, and people living with disability (PWDs) with 3.68 WAI. Here, the results point out the critical role of decision-making as to how to respond to rainy and floodable days in these urban communities. One of the limitations of this study is its inability to explore the nature of decision-making with respect to displacement of people.

Moreover, the study revealed that out of the total respondents, $86(43.9 \%)$ respondents mentioned selecting safer location to stay, while $71(36.2 \%)$ mentioned taking care of the children, the aged, and PWDs as the most applicable strategy practiced during flood in the community. Similarly, temporary relocation to nearest neighborhood until after flooding $112(57.1 \%)$, perfect communication at community level for assistance 65 (33.2\%), and taking care of the affected people $73(37.2 \%)$ were enlisted among applicable (although not highly applicable) strategies in the community for adapting to flood risk during flood. The relocation sites are mostly homes of friends and relations that have raised buildings and more spaces to accommodate people. Even under this scenario, DIY adaptation strategy is very active and effective. For instance, digging of channels to divert waters $70(35.7 \%)$ and praying for lesser rain $58(29.6 \%)$ were mentioned among moderately applicable strategies to adapt during flood. The total loss of confidence in the government manifested clearly as $27.6 \%$ of the respondents mentioned the government intervention.

\section{Post-flood Community Response on Adaptation Strategies}

Flooding can have immediate-, short-, and long-term impacts on urban communities. As such, community adaptation responses may extend to beyond the rainy season. In the context of this study, communities in the study area lack the appropriate solutions but hang on the adaptation strategies that they have developed over time. Nevertheless, our questionnaire created a kind of public conversation among the respondents who revealed their thoughts on what seems to be their perceptions of best adaptation strategies. In this regard, Table 5 outlines the roles of clearing blocked drainages in the community which was ranked as the most applicable flood adaptation strategies with a WAI of 4.11. People themselves have acknowledged the role of education as a driver of community adaptation, and this knowledge will in a long way support and enhance their capacity for DIY adaptation. This further revealed that no relief materials were received by the public in these flood-prone areas. Again, as can be seen in Table 5, the respondents stressed the need for equality in distribution of relief 


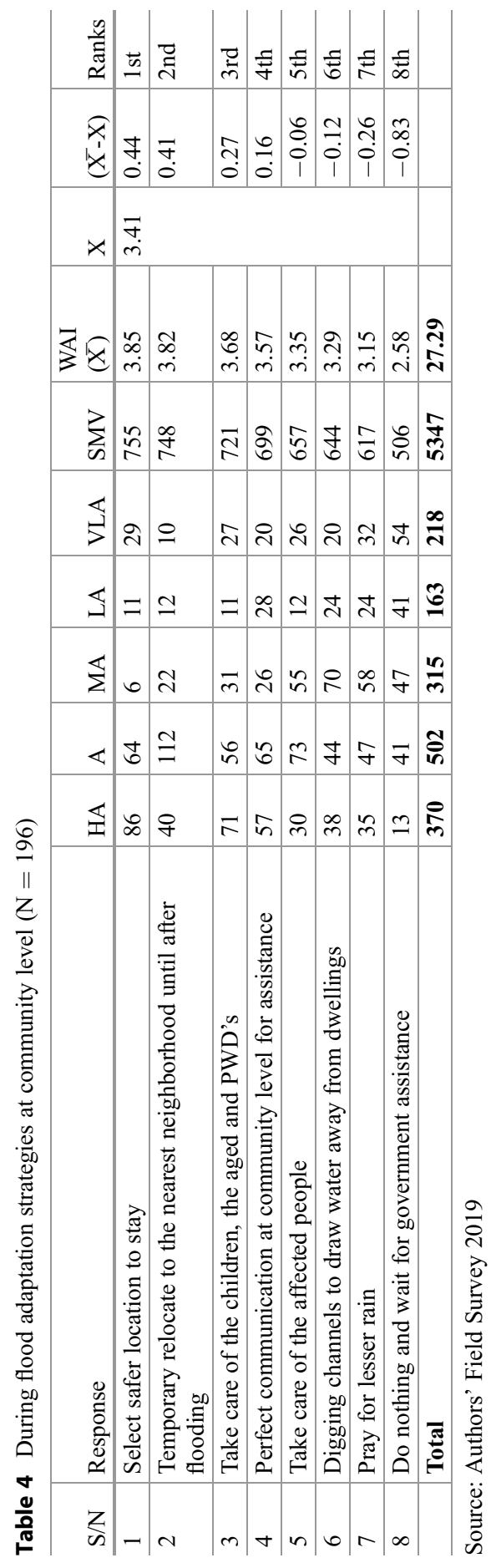




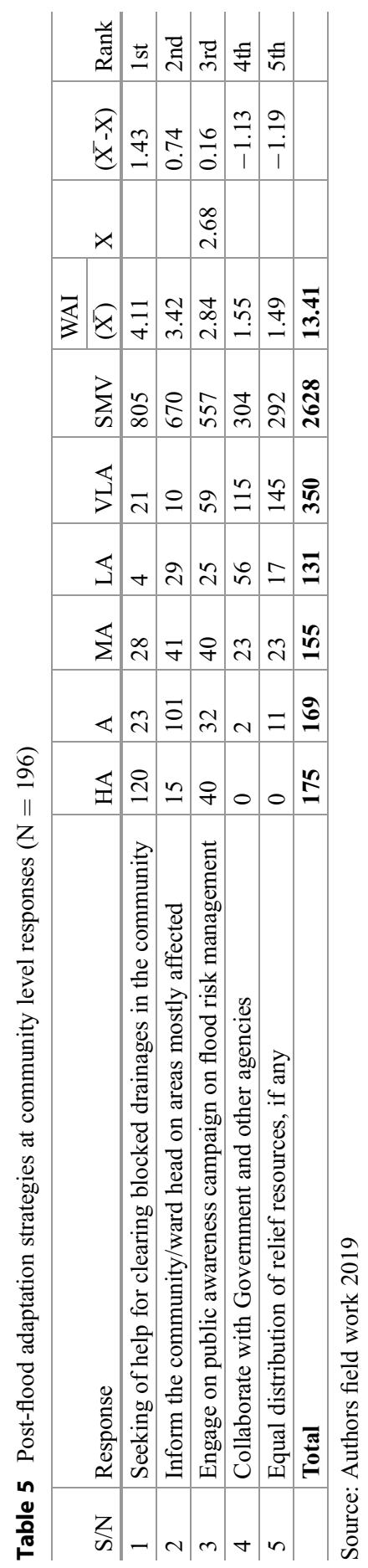




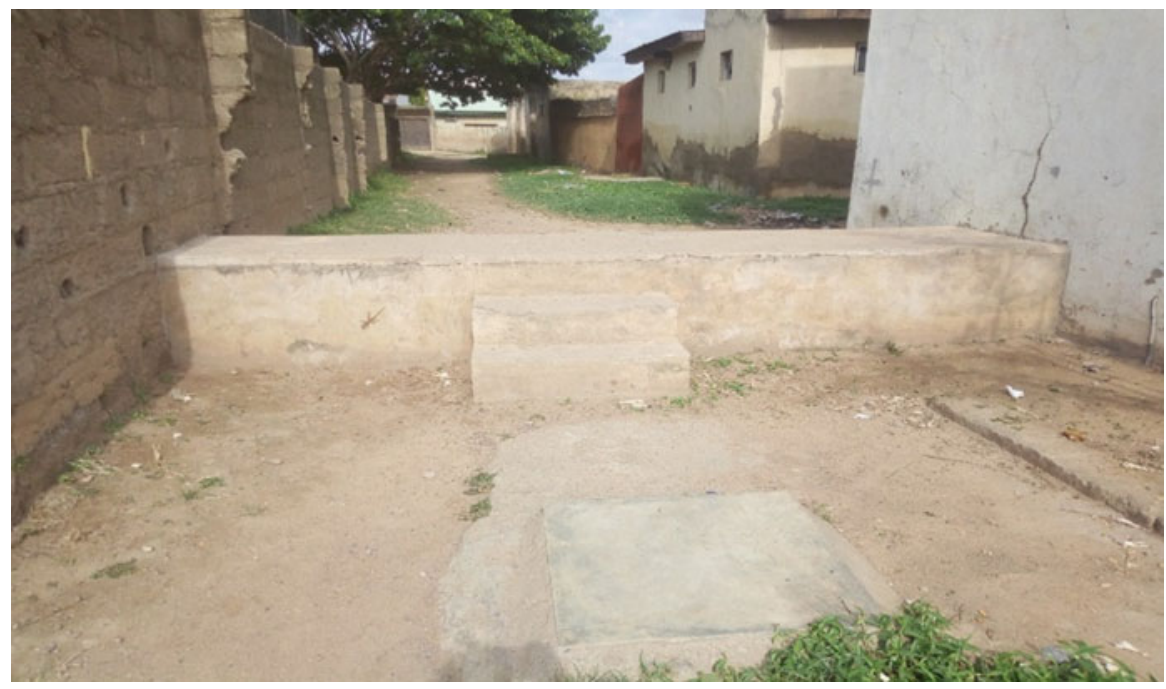

Fig. 10 Resident adaptation measures (coping strategy) to flood, to hold back and/or divert flood water away from their residence (Gwammaja)

materials from the public sector if and when at least they come to the victims of flooding. In other words, there is seemingly lack of trust on the government and its agencies for their failure to assist people. While it has been a culture for governments at all levels (local, state, federal) to allocate for disasters such as the recurrent floods, there is dissatisfaction from the side of the vulnerable communities. Again, as can be seen in Figs. 10 and 11, there is evidence of community DIY actions that aim at protecting neighborhoods and their households from recurrent flood incidents.

\section{Institutional Flood Adaptation Response Strategies in the Study Area}

Public institutions such as agencies have duty and responsibility to promote adaptation measures within their area of constitutional jurisdiction and governance system operational in a given urban area. Against this backdrop, this study sought for explanations from relevant agencies which in this case are two organizations, namely, Kano State Urban Planning and Development Authority (KNUPDA) and State Emergency Relief and Rehabilitation Agency (SERERA). In the case of KNUPDA, our questions were answered by the Zonal Coordinator who is in charge of development control in the study area. By virtue of his knowledge of the area, he affirmed that "the problem of flood in the local government is not a new phenomenon," adding that the study site is "among the ancient settlement in the state which existed for long prior to initiation of the Control Department (CD) or KNUPDA itself." This view impliedly suggests that probably the planning authority has been 


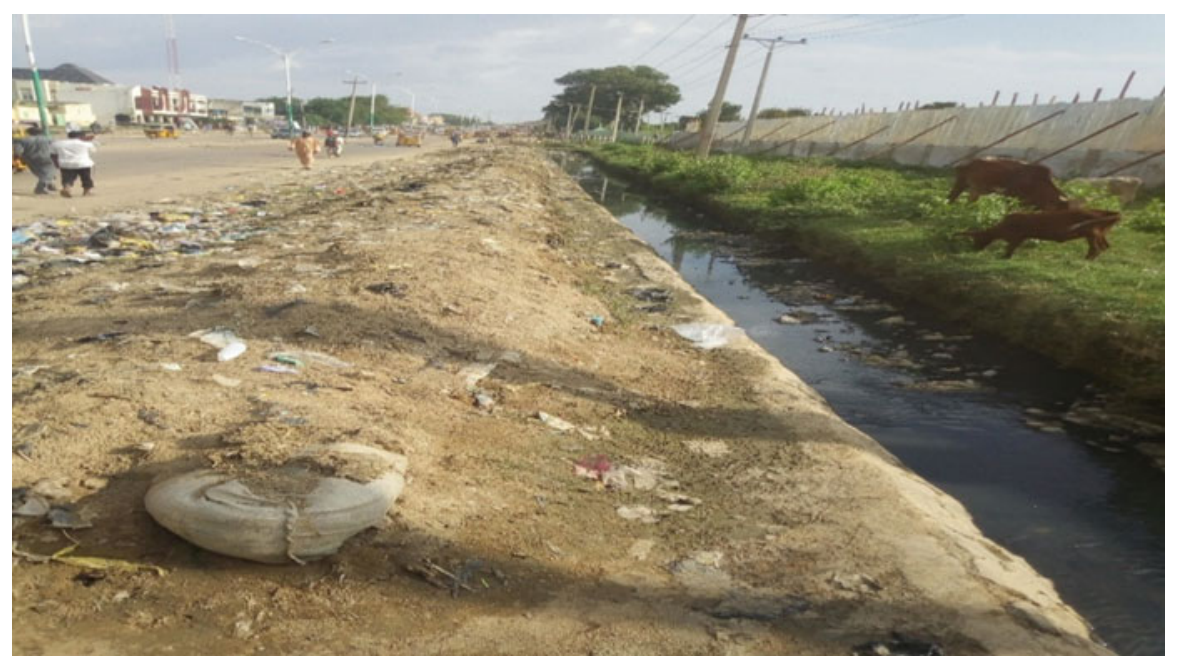

Fig. 11 De-siltation of drainages to improve free flow of storm water, but not properly evacuated which have tendency of finding its way back into the drainage

overwhelmed with the flood incident in the study area and possibly lacks sustainable solutions for the challenge. Given the experience of the United States, it is important for authorities in developing countries to tap on community initiatives in dealing with flood hazards (Noonan and Sadiq 2018).

Furthermore, the officer argued that "increased population and urbanization make the community continue to become more congested." In addition, he mentioned that there were numerous buildings that were developed without planning approval and that majority of the area was not properly planned or designed. Accordingly, such haphazard developments are among the key drivers of perennial floods. The situation is also not unconnected with inadequate drainages and encroachment of open spaces by private buildings among others. However, the officer maintained that some areas were but still suffer from lack of proper implementation of design principles and enforcement of planning regulations. Hence, he argued that "adaptation strategy employed is insisting on people to seek proper approval and development permit before construction." In doing so, KNUPDA provides prospective developers with adequate standards in developing their properties. According to him, they also convey messages to the ward heads as a mean of ensuring control of development and stop any development that encroaches floodplain in the Local Government Area which eventually might pose a problem such as environmental hazard.

With regard to the implementation and enforcement of planning regulations, the key informant asserts that "some officials are always in constant inspection of the area and these officers are responsible for reporting (immediately) any suspicious development." Another notable problem noted by the officer is the lack of proper waste collection and disposal infrastructure in the ancient city of Kano. Although poor waste disposal is invariably connected to flooding, the officer noted that waste 
management is no longer the business of KNUPDA as it has been assigned to another authority. Nevertheless, he insisted that KNUPDA had severally issued stop work notice and in some instances demolished hazardous structures when they are deemed to constitute a threat to safety. Some areas within and around the study area hardly experience flood incident and attributed that to their interventions in the local government area.

In SERERA, an agency responsible for responding to all forms of disasters in the state, the key informant revealed that they "don't have pre-flood adaptation measures" because they only embark on emergency response with immediate effect when it is reported to them. This agency does provide parties affected with relief materials ranging from building materials like cement, blocks, nails, and planks, among others. They also embark on assessment reports, making recommendations for relief measures, occasional involvement in the distribution of relief materials, and evacuation of stranded persons in spots of emergency. The respondents added that their personnel were trained on how to rescue individuals from either fire or flood disaster which is sent on special assignment when the need arises.

When asked on whether they have any special plans for the identified flood-prone areas under study, they responded that that they just act in case of emergency and provide relief materials; things provided include mosquito nets, foodstuffs, drugs, mattresses, temporary camping of stranded people, as well as taking care of the aged and children. Their response is mainly on immediate report of accidents, and they work hand in hand with fire service department whose mandate include rescue services.

Based on information given by the key informants, it is obvious there is disconnect between the approaches and philosophies of communities and public institutions responsible for tackling climate disasters and, in particular, flooding. The recurrent floods cause loss and damage to communities, and this situation increases temporary loss of shelter or displacement from their houses. This is an indication of the situation in many developing countries where there is disconnect between planning policy and climate change mitigation and adaptation. It is obvious there is need for capacity building and reorientation of urban climate change governance architectures to enable creation of a broad-based consultations and policy formulations between communities and public agencies. This is necessary because at the moment actions by communities and the agencies do not complement each other. At the same time, there is fragmentation even between and within public organizations responsible for urban planning, waste management, and rescue operations.

\section{Conclusion}

This chapter is premised on the socioecological notions which enables to gain a better understanding of flood adaptation response in urban areas of developing countries. In other words, it is imperative to look into the connections of human and social dimension of environmental and climate change as we observe climate vulnerability in cities and towns. This chapter has established the critical role of the 
physical environmental features such as relief and topography and their interface with flood incidence in high-density urban areas. Thus, it is crucial to recognize the role of physical terrain when planning and designing human settlements in this age of changing climate. In relation to this, municipalities in developing countries should prioritize the importance of systematic environmental data in urban planning climate adaptation strategies. The recurrence of flooding in cities and towns cannot be disconnected with neglect of terrain factor in stormwater overflows and its redistribution within the built-up areas. Again, as urban surface is becoming more impervious and waterproofed, it is important to reconsider the place of nature in tackling climate change.

The neglect of nature in urban development is closely followed by neglect of people in the effective management of climate crisis and, in particular, perennial floods that ravage cities and towns. It appears that in developing countries public agencies operate in silos even when there is evidence of commitments to addressing climate challenges. Therefore, it is high time to address such gaps and disconnects which cause failures and loss of time and resources due to such unyielding interventions. Invariably, the persistence of fragmented efforts leaves public to suffer resounding devastation of infrastructure as well as people's dwelling places and sources of livelihoods.

More people inhabit urban areas more than ever before in human history, and this human dominance is being challenged by climate change and its impacts. The neglect of climate vulnerable groups inhabiting informal areas has continued in most developing countries. This situation violates the principles and goals of the United Nations' Sustainable Development Goals (SDGs) and, in particular, the SDG 11 - which focus on sustainable human cities and communities. In a situation like this, one of the best options left for the people left out in the schemes of policy and planning is DIY adaptation. This adaptation strategy is found to be effective and useful to many poor and neglected urban citizens in developing countries. Hence, it is imperative on local authorities to support such efforts by working with communities that use this kind of adaptation measures. What is most attractive about DIY adaptation is that it focuses on directly correcting or tackling flood causative and/or multiplier factors. Therefore, researchers and especially climate experts and scientists need to recognize DIY as part of the grassroots efforts and local knowledge and actions which are essential in building global climate adaptation.

\section{References}

Aerts JCJH, Botzen WJ, Clarke KC, Cutter SL, Hall JW, Merz B, Mysiak J, Surminski S, Kunreuther H (2018) Integrating human behaviour dynamics into flood disaster risk assessment. Nat Clim Change. https://doi.org/10.1038/s41558-018-0085-1

Akukwe TI (2014) Determinants of flooding in Port Harcourt Metropolis, Nigeria. Int J Humanit Soc Sci 19(11):64-72

Alfieri L, Feyen L, Di Baldassarre G (2016) Increasing flood risk under climate change: a pan-European assessment of the benefits of four adaptation strategies. Clim Change 136(34):507-521. https://doi.org/10.1007/s10584-016-1641-1 
Azua S et al (2019) Spatial multi-criteria analysis for mapping of flood vulnerable areas in Fagge Local Government Area of Kano State, Nigeria. FUTY J Environ 13(1):23-35

Bai X, Dawson RJ, Ürge-Vorsatz D, Delgado GC, Salisu Barau A, Dhakal S, Dodman D, Leonardsen L, Masson-Delmotte V, Roberts DC, Schultz S (2018) Six research priorities for cities and climate change. Nature 555(7694):23-25. https://doi.org/10.1038/d41586-01802409-z

Barau AS (2008) An appraisal of climate change risks and institutional adaptation strategies in Kano State. In Association of Nigerian Geographers 50 th Annual Conference Book of Proceedings. The Department of Geography and Regional Planning, University of Calabar, Index Book Publishers, Calabar, p 113-120

Barau A, Tanko AI (2018) In search of new narratives for informed decisions on climate change crisis in the African Drylands. In: Leal Filho W, et al (eds) Handbook of climate change communication: vol 3, Climate change management. Springer International Publishing, pp 120. https://doi.org/10.1007/978-3-319-70479-1_1

Barau AS, Ludin ANM, Said I (2013) Socio-ecological systems and biodiversity conservation in African city: insights from Kano Emir's Palace gardens. Urban Ecosyst. https://doi.org/10.1007/ s11252-012-0276-X

Barau AS, Maconachie R, Ludin ANM, Abdulhamid A (2015) Urban morphology dynamics and environmental change in Kano, Nigeria. Land Use Policy 42:307-317

Cirella GT, Iyalomhe FO (2019) Determinants of flooding and strategies for mitigation: two-year case study of Benin City, pp 1-15. https://doi.org/10.3390/geosciences9030136

Colenbrander S, Barau A (2019) Planning and financing urban development in the context of the climate crisis. Int J Urban Sustain Dev 11(3):237-244. https://doi.org/10.1080/19463138.2019. 1673529

Devkota RP, Cockfield G, Maraseni TN (2014) Perceived community-based flood adaptation strategies under climate change in Nepal. August. https://doi.org/10.1504/IJGW.2014.058758

Dhiman R, Vishnuradhan R, Arun TIE (2019) Flood risk and adaptation in Indian coastal cities: recent scenarios. Appl Water Sci 9(1):1-16. https://doi.org/10.1007/s13201-018-0881-9

Fuchs S, Karagiorgos K, Kitikidou K, Maris F, Paparrizos S, Thaler T (2017) Flood risk perception and adaptation capacity: a contribution to the socio-hydrology debate. Hydrol Earth Syst Sci. https://doi.org/10.5194/hess-21-3183-2017

Haque AN, Grafakos S, Huijsman M (2012) Participatory integrated assessment of flood protection measures for climate adaptation in Dhaka. 24(1):197-213. https://doi.org/10.1177/ 0956247811433538

Jongman B (2018) Effective adaptation to rising flood risk. 9-11. https://doi.org/10.1038/s41467018-04396-1

Kubal C, Haase D, Meyer V, Scheuer S (2009) Integrated urban flood risk assessment - adapting a multicriteria approach to a city. Nat Haz Earth Syst Sci 9:1881-1895

Merz B, Hall J, Disse M, Schumann A (2010) Fluvial flood risk management in a changing world. Hydrol Earth Syst Sci 10:509-527

Muo A (2015) Evaluating the causes of flooding in six communities in Awka Anambra State of Nigeria. J Nat Sci Res 5(4):1-10

Mustapha A, Yakudima II, Alhaji M, Nabegu AB, Adamu F, Dakata G, Umar YA, Musa BU (2014) Overview of the physical and human setting of Kano. Research Journali's Journal of Geography $1(5): 1-12$

Nkwunonwo UC, Whitworth M, Baily B (2016) Review article: a review and critical analysis of the efforts towards urban flood risk management in the Lagos region of Nigeria. 349-369. https:// doi.org/10.5194/nhess-16-349-2016

Noonan DS, Sadiq AAA (2018) Flood risk management: exploring the impacts of the community rating system program on poverty and income inequality. Risk Anal. https://oi.org/10.1111/ risa. 12853 
Oculi N, Stephenson SR (2018) Conceptualizing climate vulnerability: understanding the negotiating strategies of small island developing states. Environ Sci Policy 85:72-80. https://doi.org/ 10.1016/j.envsci.2018.03.025

Olanrewaju CC, Chitakira M, Olanrewaju OA, Louw E (2019) Impacts of flood disasters in Nigeria: A critical evaluation of health implications and management. Jamba 11(1):557

Parsons M (2019) Extreme floods and river values: a social-ecological perspective. River Res Appl. https://doi.org/10.1002/rra.3355

PDNA (2013) Nigeria Post-Disaster Needs Assessment (PDNA) 2012 Floods. May

Salami RO, Giggins H, Salami R, Meding V (2016) Vulnerability of human settlements to flood risk in the core area of Ibadan metropolis, Nigeria. Jamba: Journal of Disaster Risk Studies 9(1)1-14.

Sanni D, Okhimamhe A (2009) Linking climate change and urbanization in Kano Metropolis and environs in the Sudano-Sahelian Belt of Nigeria, IOP Conf. Series: Earth and Environmental Science 6(2009) 342032. https://doi.org/10.1088/1755-1307/6/4/342032

Schanze J (2006) Flood risk management - a basic framework. In: Schanze J, Zeman E, Marsalek J, editors. Flood risk management - hazards, vulnerability and mitigation measures. NATO Science Series. Houten: Springer Netherlands; p. 120

Soneye A (2014) An overview of humanitarian relief supply chains for victims of perennial flood disasters in Lagos, Nigeria (2010-2012). J Humanit Log Supply Chain Manag 4:179-197

Udelsmann Rodrigues C (2019) Climate change and DIY urbanism in Luanda and Maputo: new urban strategies? Int J Urban Sustain Dev. https://doi.org/10.1080/19463138.2019.1585859

Verburg PH, Koomen E, Lesschen JP (2012) An assessment of the impact of climate adaptation measures to reduce flood risk on ecosystem services. 473-486. https://doi.org/10.1007/s10980012-9715-6

Vojtek M, Vojteková J (2016) Flood hazard and flood risk assessment at the local spatial scale: a case study. 5705. https://doi.org/10.1080/19475705.2016.1166874

Wilby RL, Keenan R (2012) Adapting to flood risk under climate change. https://doi.org/10.1177/ 0309133312438908

Yamane T (1967) Statistics, An Introductory Analysis, 2nd Ed., New York: Harper and Row

Open Access This chapter is licensed under the terms of the Creative Commons Attribution 4.0 International License (http://creativecommons.org/licenses/by/4.0/), which permits use, sharing, adaptation, distribution and reproduction in any medium or format, as long as you give appropriate credit to the original author(s) and the source, provide a link to the Creative Commons license and indicate if changes were made.

The images or other third party material in this chapter are included in the chapter's Creative Commons license, unless indicated otherwise in a credit line to the material. If material is not included in the chapter's Creative Commons license and your intended use is not permitted by statutory regulation or exceeds the permitted use, you will need to obtain permission directly from the copyright holder.

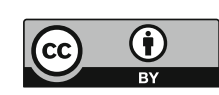

